\title{
Hazards Assessment Document for Receiving Basin for Offsite Fuel (244-H) and Resin Regeneration Facility $(245-\mathrm{H})$ (RBOF/RRF) (U)
}

A. N. Miner

S. F. Ortaldo

JULY, 1994

Westinghouse Savannah River Company Engineering and Projects Division Aiken, SC 29808

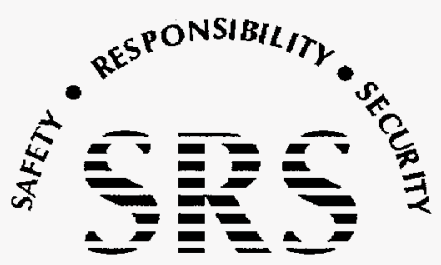

PREPARED FOR THE U.S. DEPARTMENT OF ENERGY UNDER CONTRACT NO. DE-AC0989SR18035

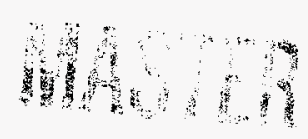




\section{DISCLAIMER}

This report was prepared as an account of work sponsored by an agency of the United States Government. Neither the United States Government nor any agency thereof, nor any of their employees, makes any warranty, express or implied, or assumes any legal liability or responsibility for the accuracy, completeness, or usefulness of any information, apparatus, product, or process disclosed, or represents that its use would not infringe privately owned rights. Reference herein to any specific cornmercial product, process, or service by trade name, trademark; manufacturer, or otherwise does not necessarily constitute or imply its endorsement, recommendation, or favoring by the United States Government or any agency thereof. The views and opinions of authors expressed herein do not necessarily state or reflect those of the United States Government or any agency thereof.

This report has been reproduced directly from the best available copy.

Available to DOE and DOE contractors from the Office of Scientific and Technical Information, P.O. Box 62, Oak Ridge, TN 37831; prices available from (615) 576-8401.

Available to the public from the National Technical Information Service, U.S. Department of Commerce; 5285 Port Royal Road, Springfield, VA 22161. 


\section{DISCLAIMER}

Portions of this document may be illegible in electronic image products. Images are produced from the best available original document. 
Project: Hazards Assessment Documents

Document: $\quad$ WSRC-TR-94-054, Rev. 0

Title: Hazards Assessment Document

DOE-STD-1027-92 Review

Buildings $244-\mathrm{H}$ and $245-\mathrm{H}$

APPROVALS:

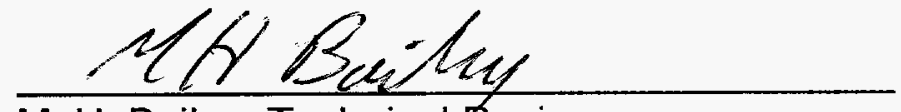

M. H. Bailey, Technical Reviewer

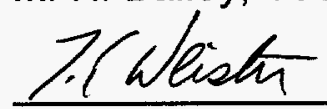

T. E. Weister, Manager, TAF

$$
\text { NL/tanos }
$$

W. E. Harris, Manager, NMPD/SS

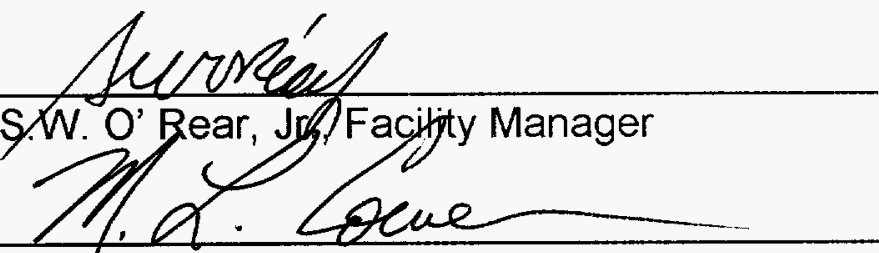

M. L.'Cowen, Manager, SSS

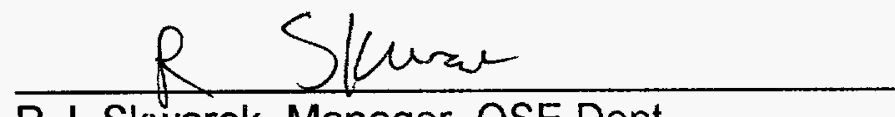

R.J. Skwarek, Manager, OSE Dept.

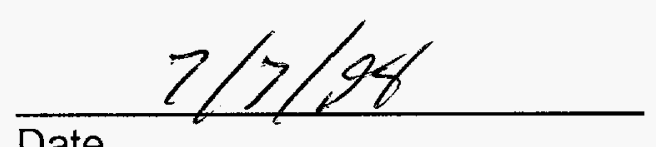

Date

$$
7-7-94
$$

Date

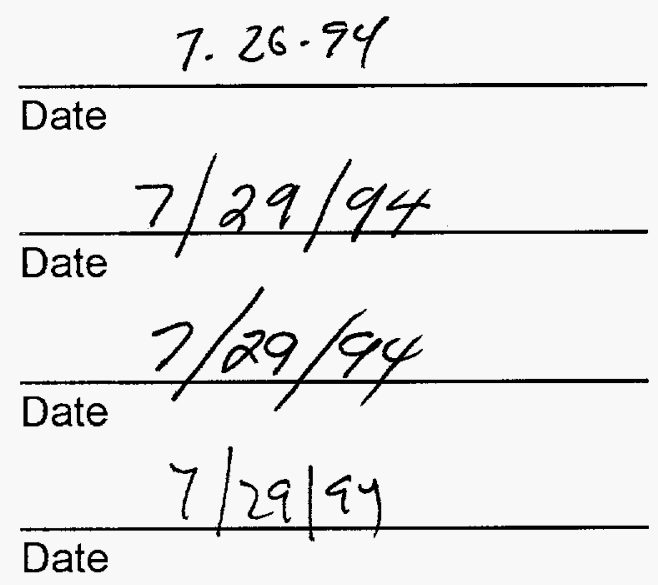




\section{REVISION HISTORY}

$\underline{\text { Revision }}$

0
Affected Pages

All
Description of Revision

Original Issue 


\section{TABLE OF CONTENTS}

1.0 SUMMARY

6

2.0 INTRODUCTION

6

3.0 NUCLEAR FACILITY CLASSIFICATION

4.0 HAZARD CATEGORIZATION METHODOLOGY

5.0 ASSUMPTIONS

6.0 HAZARDOUS MATERIAL INVENTORY

7.0 HAZARD ANALYSIS CATEGORIZATION

8.0 RESULTS AND CONCLUSIONS

9.0 REFERENCES 


\subsection{SUMMARY}

The Hazard Assessment Document (HAD) for the Receiving Basin for Offsite Fuels (RBOF), Building 244-H, and the Resin Regeneration Facility (RRF), Building 245-H, was prepared in accordance with Department of Energy (DOE) Order 5480.23 [1], DOE-STD-1027-92 [2], and WSRC-MS-92-206 [3]. The HAD provides hazards categorizations based on the radiological and chemical hazards associated with the facility. The hazard category is used to provide the input data for a graded approach to the development of the facility Safety Analysis Report (SAR) in accordance with DOE Order 5480.23. The RBOF/RRF was assumed to be a one segment facility. The accident consequences are calculated without consideration for any mitigative systems or administrative controls

This facility is categorized as Hazard Category 2 as a result of the analysis of the radiological inventory conducted in accordance with Reference 2 and the chemical inventory in accordance with Reference 3.

Table 1 lists the maximum radionuclide inventory for this facility, and Tables 2 and 3 list the maximum chemical inventory.

\subsection{INTRODUCTION}

\subsection{Background}

The major objective of a hazard categorization is to provide the input data for a graded approach to the development of the facility Safety Analysis Report (SAR) in accordance with DOE Order 5480.23. To satisfy this objective, accident consequences are calculated using extremely conservative methods without consideration for any mitigation systems or administrative controls. Therefore, the numerical results should not be used in any other context. Specifically, the results should not be confused with the result reported in the SARs in which appropriate consideration is given to mitigation systems and administrative controls. The focus of this hazards assessment is on the impact of maximum energy or material source term release, without credit for controls or regard for event frequency.

To comply with DOE guidance, the hazard categorization is based upon comparing the facility inventories against threshold quantities of radionuclides as set forth in DOE-STD-1027-92. A summary of this methodology is provided in Section 3. The hazards analysis does not take credit for engineered safety features or administrative controls except for the limit placed on the inventory for this evaluation. Because this methodology of hazard categorization is based upon a maximum facility inventory relative to radionuclide quantities, it is not necessary to perform atmospheric dispersion calculations or to determine the most appropriate source release fraction for each likely accident scenario. DOE-STD-1027-92 provides guidance for establishing an inventory limit for all radionuclides. 


\subsection{Facility Description}

The RBOF Facility supports the Separations Areas. Building 244-H, Receiving Basin for Offsite Fuels (RBOF), and Building 245-H, Resin Regeneration Facility (RRF), are adjoining buildings. Figure 1 shows the location of the Separations Area (H-Area), within the Savannah River Site. Figure 2 shows the location of Buildings 244-H and $245-\mathrm{H}$ within $\mathrm{H}$-area. The purpose of the RBOF Facility is to receive cask shipments via rail or truck, unload the cask underwater, inspect and prepare fuel for processing, and then store and/or transship the fuels from the facility. The RRF is capable of regenerating both anion and cation type ion exchange resins. Normally, it is utilized to regenerate the resin used for deionization of Building $244-\mathrm{H}$ water and the resin used in the portable deionizer to deionize the 100-Area water systems, but it is flexible enough to provide regeneration capability for any resin that can be brought to the facility.

\subsection{NUCLEAR FACILITY CLASSIFICATION}

A Nonreactor Nuclear Facility is defined in DOE Order 5480.23 [1], Section 5.k, as "...those activity or operations that involve radioactive and/or fissionable materials in such form and quantity that a nuclear hazard potentially exists to the employees or general public. Included are activities or operations that: 1) produce, process or store radioactive liquid or solid waste, fissionable materials, or tritium; 2) conduct separations operations; 3 ) conduct irradiated materials inspection, fuel fabrication, decontamination, or recovery operations; 4) conduct fuel enrichment operations; or 5) perform environmental remediation or waste management activities involving radioactive materials.

Incidental use and generating of radioactive materials in a facility operation (e.g., check and calibration sources, use of radioactive sources in research, experimental and analytical laboratory activities, electron microscopes, and-ray machines) would not ordinarily require the facility to be included in this definition."

The RBOF/RRF contains radioactive and fissile materials in such quantity that a nuclear hazard potentially exists, and therefore it is classified as a Nonreactor Nuclear Facility. Therefore, the facility may be subject to the design criteria outlined in DOE Order 6430.1A [4], Division 13.

\subsection{HAZARD CATEGORIZATION METHODOLOGY}

This methodology will describe ways to perform radiological, chemical and criticality hazards evaluations and will categorize the facility. The criteria for determining the radiological hazard categorization of the RBOF/RRF are provided in DOE-STD-102792. The criteria for determining the chemical hazard categorization are provided in WSRC-MS-92-206. The criteria for determining the criticality hazard categorization are provided in ANSI/ANS-8.1. 
In DOE Order 5480.23 [1], there are three hazard categories. A facility is categorized as Hazard Category 1 if the hazard analysis shows significant offsite consequences, Hazard Category 2 if the hazard analysis shows the potential for significant onsite consequences, and Hazard Category 3 if the hazard analysis shows the potential for significant localized consequences only. In this analysis, a facility that does not meet or exceed the Hazard Category 3 threshold criteria but still possesses some amount of radioactive material is considered a Radiological Facility.

The radionuclide and chemical evaluations begin by comparing inventories to several accepted standards. The radiological evaluation is accomplished by comparing the inventory of each radionuclide to the threshold quantity provided in Table A.1 of DOESTD-1027-92. The analysis of the chemical inventory begins with the comparison of each chemical to the Reportable Quantities (RQs) of 40 CFR 302.4 [5], the Threshold Planning Quantities (TPQs) of 40 CFR 355 [6], and the Threshold Quantities (TQs) of 29 CFR 1910.119 [7]. A hazard assessment is not required for any chemicals that do not exceed the RQs, TPQs, or the TQs because the chemicals in the quantities less then those listed are generally accepted by the public. Following the initial screening process, the chemicals are evaluated in accordance with the criteria of WSRC-MS-92206. The fissionable materials are evaluated per ANSI/ANS-8.1[22] standard.

The criteria for determining the hazard categorization based on the radiological evaluation, chemical evaluation and criticality are described below.

Hazard Category 1 - A facility is categorized as Hazard Category 1 if either criteria A or $B$ are met.

A. The facility has the potential for significant offsite consequences based on the total curie content, potential material forms, and maximum energy of dispersion available.

Only Category A Reactors or facility designated by the Program Secretarial Officer (PSO) are designated as Hazard Category 1 in accordance with the directions of DOE-STD-1027-92.

B. A postulated release of any hazardous chemical results in an airborne concentration greater than or equal to its Emergency Response Planning Guideline 3 (ERPG-3) value at the site boundary.

- or -

For chemical compounds that have been identified as confirmed or suspected carcinogens, the calculated Incremental Cancer Risk (ICR) is greater than or equal to $2.00 \mathrm{E}+00$ at the site boundary. 
Hazard Category 2 - A facility is categorized as Hazard Category 2 if any of the following criteria are met.

A. The quantity of any radionuclide exceeds the Hazard Category 2 threshold quantity provided in Table A.1 of DOE-STD-1027-92. This quantity is based on 1 rem at 100 meters as determined in 10 CFR 30 [21] and as modified by DOE.

B. The minimum critical mass limit for any fissile material, as specified in ANSI/ANS-8.1 [22], is exceeded.

C. The total quantity of mixed fission products, where the individual radionuclides have not been determined, is greater than 1000 curies.

D. A postulated release of any hazardous chemical results in an airborne concentration greater than or equal to its ERPG-3 value at a distance of 100 meters (onsite).

- or -

For chemical compounds that have been identified as confirmed or suspected carcinogens, the calculated ICR is greater than or equal to $2.00 \mathrm{E}+00$ at the distance of 100 meters (onsite).

Hazard Category 3 - A facility is categorized as Hazard Category 3 if either criteria A or $B$ are met.

A. The quantity of any radionuclide exceeds the Hazard Category 3 threshold quantity provided in Table A.1 of DOE-STD-1027-92. This quantity is based on 10 rem at 30 meters for a 24-hour exposure.

B. A postulated release of any hazardous chemical results in an airborne concentration greater than or equal to its ERPG-3 value locally at the facility.

- or -

For chemical compounds that have been identified as confirmed or suspected carcinogens, the calculated ICR is greater than or equal to $2.00 \mathrm{E}+00$ locally at the facility

The analysis to determine the hazard categorization is performed without credit being taken for engineered features or administrative controls. Examples of engineered features and administrative controls are those specific facility features (not including site location), such as building containment, stacks, equipment, systems, actions, or operating conditions, that are established to control risk. This approach allows credit to be taken for existing location and the physics of material release and dispersion, but not for containment, confinement, shielding, protection systems, administrative controls, or human activities. 


\subsection{ASSUMPTIONS}

The following assumptions were made to perform the analysis:

- No credit is taken for engineered features or administrative controls.

- If the Threshold limits for a radionuclide were not listed in DOE-STD-102792 , or they could not be found via NE-70 of the DOE, the quantity of that particular radionuclide was compared to the Category 2 Threshold limit for alpha or beta-gamma emitters, per DOE-STD-1027, and categorized appropriately.

- Both the onsite and offsite chemical concentrations were calculated using $\chi / Q$ values derived from an AXAIR89Q [8] computer run. The calculations used the following parameters:

- The onsite receptor is located downwind at a distance of 100 meters in the worst meteorological sector. (The highest $\chi / Q$ value at 100 meters is $3.66 \mathrm{E}-03 \mathrm{sec} / \mathrm{m}^{3}$ in the north-northeast sector.)

- The offsite receptor is located at the site boundary in the worst meteorological sector. (The highest $\chi / Q$ value at the site boundary is $5.47 \mathrm{E}-06 \mathrm{sec} / \mathrm{m}^{3}$ in the north sector. The distance to the site boundary in this sector is $11.87 \mathrm{~km}$.)

- The $\chi / Q$ values obtained from AXAIR89Q are really only one-hour $\chi / Q s$ which have been set equal to two hour $\chi / Q$ s to provide a level of conservatism. In order to transform the two hour $\chi / Q$ s obtained from AXAIR89Q to 15 minute $\chi / Q$ s and retain the inherent conservatism, the following formula is applied [9]:

$$
\frac{(\chi / Q)_{15}}{(\chi / Q)_{120}}=\left(\frac{120}{15}\right)^{0.2}=1.516
$$

Therefore, the onsite and offsite $\chi / Q$ values used for this analysis are $5.55 \mathrm{E}-03 \mathrm{sec} / \mathrm{m}^{3}$ and $8.29 \mathrm{E}-06 \mathrm{sec} / \mathrm{m}^{3}$ respectively.

- The local chemical concentrations were calculated using a $\chi / Q$ value that was determined from Areal Locations of Hazardous Atmospheres (ALOHA) computer run output data (Version 5.05) [10]. The calculations used the following parameters: 
- The local receptor is located at a distance of 30 meters from the postulated release. (The $\chi / Q$ value at 30 meters is $1.75 \mathrm{E}-02 \mathrm{sec} / \mathrm{m}^{3}$.)

- The ALOHA data input assumed a 4.5 meters $/ \mathrm{sec}$ wind speed and Class D stability ( 9 tenths cloud cover corresponds to Class D) [3]. The remainder of the ALOHA data inputs (relative humidity, air temperature, ground roughness, etc.) were conservatively chosen.

- The following assumptions were applied to the EPA air emission model [11]:

- Spill area is circular (width = length)

- Spill thickness or depth $=1 \mathrm{~cm}[12]$

- Wind speed $=150 \mathrm{~cm} / \mathrm{sec}[12]$

- Temperature $=298 \mathrm{~K}$

- For two phase aqueous/organic waste, the organic phase is assumed to cover the entire surface of the liquid [11]

\subsection{HAZARDOUS MATERIAL INVENTORY}

\subsection{Radiological Inventory}

The maximum radionuclide inventory for the RBOF/RRF was obtained from N-CLC-H0084 [24], and is listed in Table 1.

\subsection{Chemical Inventory}

The various chemicals are stored on a series of chemical pads [23]; however, for this analysis, the RBOF/RRF was treated as a single segment. Tables 2 and 3 list the concentration, form, and amount of the individual chemicals as listed in SRT-SEP-940012 [23].

\subsection{Fissile Material Inventory}

The radiological inventory for the RBOF/RRF contained three fissile radionuclides (U-233, U-235, and Pu-239) that present a potential criticality hazard for the facility. The minimum critical mass limits for the fissile materials are included in DOE-STD1027-92 [2]. The inventory of fissile radionuclides and the minimum critical mass limits are given in Table 8 . 


\subsection{HAZARDS ANALYSIS AND CATEGORIZATION}

\subsection{Radiological Hazards Analysis and Categorization}

The radiological analysis involved an evaluation of the maximum radionuclide inventory in the RBOF/RRF. In accordance with the methodology of Section 3.1, the inventory was compared to the threshold limits provided in Table A.1 of DOE-STD-1027-92. As shown above in Table 1, this comparison demonstrated the following:

- The actual inventory of some radionuclides in the facility was greater than their Hazard Category 2 threshold limits.

- The sum of the ratios of the quantity of each radionuclide to the Hazard Category 2 Threshold limit was greater than one

- The total quantity of mixed fission products in the RBOF/RRF is greater than 1000 Curies.

Therefore based on the radiological inventory ( as seen in Table 1), this facility is categorized as a Hazard Category 2 Facility.

\subsection{Chemical Hazards Analysis and Categorization}

Assessment of the chemical inventory began with the comparison of each chemical to the Reportable Quantities (RQs) of 40 CFR 302.4 [5], the Threshold planning Quantities (TPQs) of 40 CFR 355 [6], and the Threshold Quantities (TQs) of 29 CFR1910.119 [7]. A hazards assessment was not required for any chemicals that did not exceed the (RQs) of 40 CFR 302.4, the TPQs of 40 CFR 355 or the TQs of 29 CFR1910.119, because chemicals in quantities less than those listed are generally accepted by the public. Following the initial screening process, the chemicals are evaluated in accordance with the criteria of WSRC-MS-92-206. The evaluations are provided in Tables 2-6.

The inventory of the following chemicals exceeded the associated RQs, TPQs, and TQs and required a chemical hazards analysis to determine the potential consequences of an accidental release: sulfuric acid, nitric acid, phosphoric acid, sodium nitrite, and sodium hydroxide, all in various amounts and concentrations.

For those chemicals which do not have listed RQs, TPQs, and TQs but do have Emergency Response Planning Guideline 3 (ERPG-3) or equivalent limits available for comparison, a chemical hazards analysis was required in accordance with WSRC-MS92-206. The chemicals that required analysis because of this requirement were ethylene glycol and anhydrous oxalic acid. 
An analysis was not performed for sodium nitrite because no ERPG-3 or equivalent limit was available.

A chemical hazards analysis determines the maximum offsite, onsite, and local airborne concentrations resulting from a postulated release of the chemical inventory. In addition, these maximum airborne concentrations are compared to the applicable criteria (ERPG-3 or equivalent).

A conservative analysis was performed for sulfuric acid, nitric acid, ethylene glycol, phosphoric acid, sodium hydroxide, and anhydrous oxalic acid in which it was assumed that the inventory was released within a 15 minute period [3]. A Release Fraction (RF) of $1 \%$ was conservatively applied to calculate the release rate $\mathrm{RR}, \mathrm{mg} / \mathrm{sec}$ [16]. The release rate for these chemicals was calculated as follows:

$$
R=\frac{\text { inventory }(\mathrm{lb}) \times 4.54 \mathrm{E}+05 \mathrm{mg} / \mathrm{lb} \times \mathrm{RF}}{15 \text { minutes } \times 60 \mathrm{sec} / \text { minute }}
$$

Because some of the chemicals being analyzed in the RBOF/RRF may have high vapor pressure at ambient conditions, an analysis that assumes a 1\% Release Fraction (RF) may not be conservative. Therefore, an EPA evaporation model (Open Dump Model [11]) was used, as a check, to more accurately determine the release rate for the chemicals being analyzed. If the EPA evaporation model indicated a Release Fraction larger than $1 \%$ in a 15 minute period then the more conservative (larger) Release Fraction was used in the analysis.

For the chemicals that were analyzed for the RBOF/RRF, the check confirmed that a $1 \% \mathrm{RF}$ was conservative. The actual calculated values of the release fractions can be seen in Table 9.

Upon analysis of the chemical inventory of the RBOF/RRF (as seen in Tables 3-6), and in accordance with WSRC-MS-92-206, this facility is categorized as a Hazard Category 2 Facility.

\subsection{Criticality Hazards Analysis and Categorization}

The analysis to determine if there is a potential for nuclear criticality involved converting the activity of the specific radionuclide (U-233, U-235, or Pu-239) into the mass of the radionuclide using the specific activity of the nuclide. This conversion, and the total inventory of fissile materials can be seen in Table 8 . It can also be seen in Table 8 that the total mass of fissile materials was well above the minimum critical mass limits specified in DOE-STD-1027-92 [2]. Therefore in accordance with DOESTD-1027-92, this facility must be categorized as a Hazard Category 2 Facility. 


\subsection{RESULTS AND CONCLUSIONS}

The radiological analysis performed in accordance with DOE-STD-1027-92 resulted in the facility being categorized as a Hazard Category 2 Facility. This analysis was based on the maximum radionuclide inventory expected within the facility.

The chemical analysis performed in accordance with WSRC-MS-92-206 resulted in the facility being categorized as a Hazard Category 2 Facility. This analysis was based on the maximum chemical inventory and conservative dispersion conditions.

The criticality analysis performed in accordance with DOE-STD-1027-92 resulted in the facility being categorized as a Hazard Category 2 Facility. This analysis was based on the maximum fissile materials inventory expected within the facility.

Based on the radiological, chemical and criticality analysis, the RBOF/RRF received an overall categorization as a Hazard Category 2 Facility.

The results of this evaluation are not valid for radiological or chemical inventories greater than those discussed within this analysis.

\subsection{REFERENCES}

1. Nuclear Safety Analysis Reports. DOE Order 5480.23 , U.S. Department of Energy, Washington, DC, April 30, 1992.

2. Hazard Categorization and Accident Analysis Techniques for Compliance with DOE Order 5480.23, Nuclear Safety Analysis Reports. DOE-STD-102792, U.S. Department of Energy, Washington, DC, December 1992.

3. Craig, D. K., et al. Toxic Chemical Hazard Classification and Risk Acceptance Guidelines for Use in DOE facilities. WSRC-MS-92-206, Rev. 1 (April 1993 Recommendations of the Westinghouse M\&O Subcommittee on Nonradiological Risk Acceptance Guideline Development), Westinghouse Savannah River Company, Aiken, SC, April 1993.

4. General Design Criteria. DOE Order 6430.1A, U.S. Department of Energy, Washington, DC, April 6, 1989.

5. Code of Federal Regulations, 40 CFR, Part 302.4, Protection of Environment, July, 1992. 
6. Code of Federal Regulations, 40 CFR, Part 355, Protection of Environment, July, 1992.

7. Code of Federal Regulations, 29 CFR, Part 1910.119, Labor, July 1, 1992.

8. Huang, J. C., Use of the AXAIR89Q Code WSRC-TR-90-569, December 1990.

9. Weber, A. H. "Determining Fifteen-minute $\chi / Q$ s from Two-hour $\chi / Q s$," Memorandum to R. P. Addis. Memorandum SRT-ETS-920503, Westinghouse Savannah River Company, Aiken, SC, November 8, 1993.

10. Areal Locations of Hazardous Atmospheres. Version 5.05, National Oceanic and Atmospheric Administration of the U.S. Environmental Protection Agency, Washington, DC, September 1991.

11. Hazardous Waste Treatment Storage and Disposal Facilities (TSDF) - Air Emission Models, EPA-450/3-026, U.S. Environmental Protection Agency, December, 1987.

12. Gagne, P., "HAD Chemical Evaluation Meeting Minutes", Memorandum to Jim Schornhorst, Memorandum SRA-91-855, Westinghouse Savannah River Company, Aiken, SC, December 19, 1991.

13. Inter-Office Memorandum SRT-SSA-930073, DOE-STD-1027-92 Category 3 Threshold Limits, November 22, 1993.

14. Inter-Office Memorandum SRT-SSA-930011, DOE-STD-1027-92 Category 3 Threshold Limits, October 19, 1993.

15. Inter-Office Memorandum SRT-LSA-93-0087, DOE-STD-1027-92 Category 3 Threshold Limits, June 14, 1993

16. Kim, K. S. and Waltz, W. R., Interim Hazards Classification Guide for NonReactor Facilities at Savannah River Site, July 1990.

17. NIOSH/OSHA Manual, Pocket Guide to Chemical Hazards, U.S. Department of Health and Human Services, June, 1990.

18. Inter-Office Memorandum EPD-TAF-94-0008, DOE-STD-1027-92 Category 3 Threshold Limits, June 7, 1994.

19. Inter-Office Memorandum SRT-SSA-940048, DOE-STD-1027-92 Category 3 Threshold Limits, February 18, 1994. 
20. Elder, J. C. et al. A Guide to Radiological Accident Considerations for Siting and Design of DOE Nonreactor Nuclear Facilities Report. LA-10294-MS, Los Alamos National Laboratory, Los Alamos, NM, January 1986.

21. Code of Federal Regulations, 10 CFR, Part 30, Appendix A, Energy, January 1,1989

22. ANSI/ANS-8.1, American National Standard For Nuclear Criticality Safety In Operations With Fissionable Materials Outside Reactors. American Nuclear Society, October 1983.

23. Inter-Office Memorandum SRT-SEP-94-0012, Chemical Inventory Data for the RBOF HAD (U), January 25, 1994.

24. Kahook, Saemer, Radionuclide Activity of the Bounding RBOF Fuel, Memorandum N-CLC-H-0084, Westinghouse Savannah River Company, Aiken SC, July 1994.

25. Code of Federal Regulations, 10 CFR, Part 71, Appendix A, Energy, January $1,1988$. 


\subsection{APPENDIX}

\section{$9.1 \quad$ Figures}

Figure 1 Location of $\mathrm{H}$ Area at the Savannah River Site

Figure 2 Location of Buildings $244-\mathrm{H}$ and $245-\mathrm{H}$ Within $\mathrm{H}$ Area

\subsection{Tables}

Table 1 Radionuclide Inventory and Categorization

Table 2 Chemical Inventory

Table 3 Chemical Inventory and Comparison to Reportable Quantity Limits

Table 4 Offsite Chemical Analysis Results and Equivalent ERPG-3 Limits

Table 5 Onsite Chemical Analysis Results and Equivalent ERPG-3 Limits

Table 6 Local Chemical Analysis Results and Equivalent ERPG-3 Limits

Table 7 Recommended Nonradiological Hazard Categorization Guidelines For Use With DOE Order 5480.23

Table 8 Inventory of Fissile Materials and Criticality Limits 


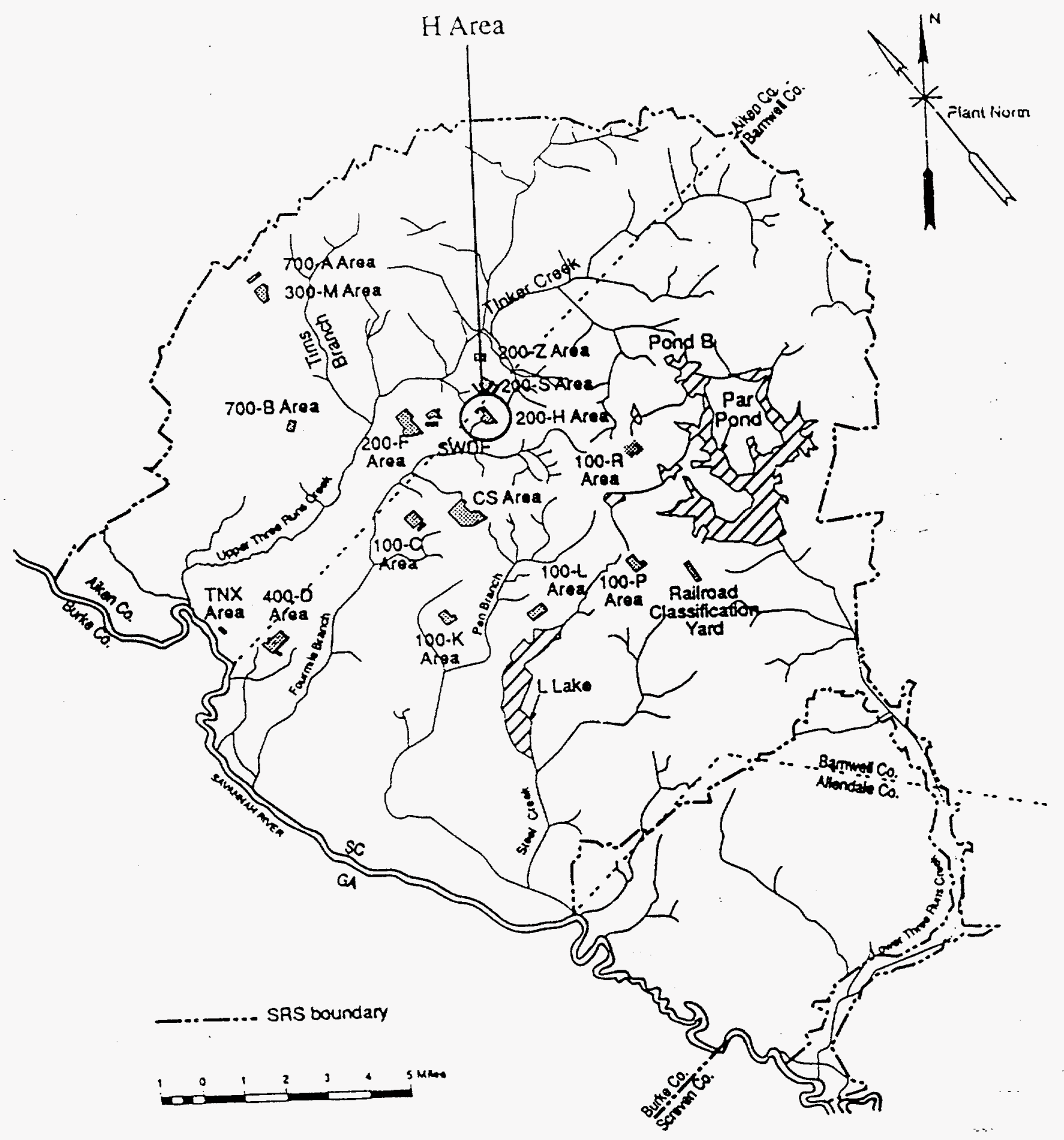

Figure 1. Location of H Area Within the Savannah River Site 


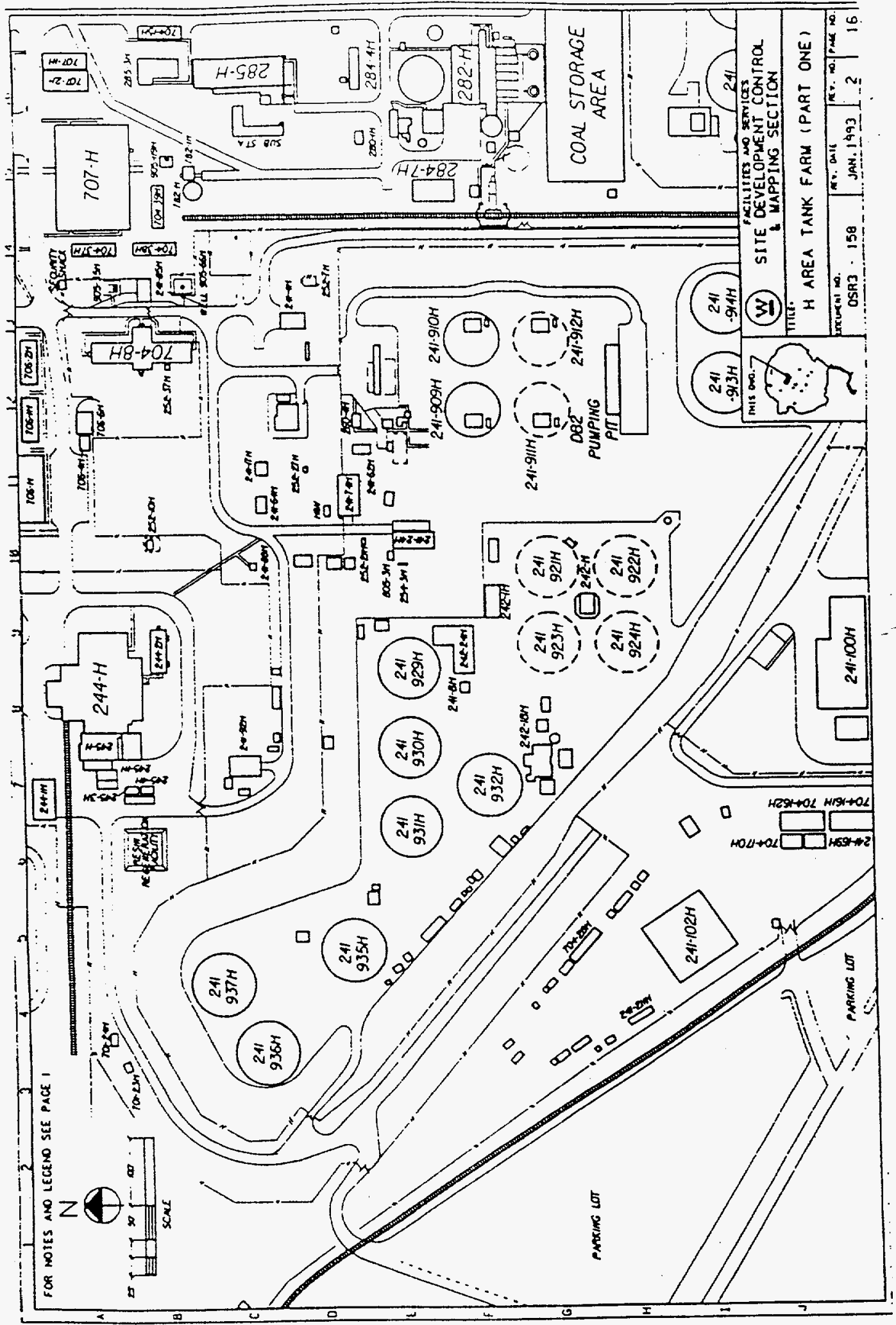

Figure 2. Location of Buildings $244-\mathrm{H}$ and $245-\mathrm{H}$ Within $\mathrm{H}$ Area 
Table 1. Radionuclide Inventory and Categorization

\begin{tabular}{|c|c|c|c|c|c|}
\hline \multirow[b]{2}{*}{ Radionuclide } & \multirow[b]{2}{*}{$\begin{array}{l}\text { Activity } \\
\text { (Curies)+ }\end{array}$} & \multicolumn{2}{|c|}{$\begin{array}{l}\text { Hazard Classification } \\
\text { Criteria (Curies) }\end{array}$} & \multirow[b]{2}{*}{$\begin{array}{l}\text { Ratio to } \\
\text { Category } 2 \\
\text { Threshold }\end{array}$} & \multirow[b]{2}{*}{$\begin{array}{c}\text { Hazard } \\
\text { Classification }\end{array}$} \\
\hline & & $\begin{array}{l}\text { Category } 2 \\
\text { Threshold }\end{array}$ & $\begin{array}{l}\text { Category } 3 \\
\text { Threshold }\end{array}$ & & \\
\hline $\mathrm{H}-3$ & $1.14 \mathrm{E}+05$ & $3.0 E+05$ & $1.0 \mathrm{E}+03$ & $3.78 \mathrm{E}-01$ & Category 3 \\
\hline $\mathrm{Kr}-85$ & $2.31 E+06$ & $2.8 \mathrm{E}+07$ & $2.0 \mathrm{E}+04$ & $8.25 \mathrm{E}-02$ & Category 3 \\
\hline Sr-89 & $1.08 E+05$ & $7.7 E+05$ & $3.4 \mathrm{E}+02$ & 1.41E-01 & Category 3 \\
\hline Sr-90 & $1.78 \mathrm{E}+07$ & $2.2 E+04$ & $1.6 \mathrm{E}+01$ & $8.08 E+02$ & Category 2 \\
\hline $\mathrm{Y}-90$ & $1.78 \mathrm{E}+07$ & $4.3 E+05^{\beta}$ & $1.41 \mathrm{E}+03^{\mathrm{C}}$ & $4.13 E+01$ & Category 2 \\
\hline$Y-91$ & $4.69 \mathrm{E}+05$ & $6.5 E+05$ & $3.6 E+02$ & $7.21 \mathrm{E}-01$ & Category 3 \\
\hline Zr-93 & $9.99 E+05$ & $8.9 E+04$ & $6.2 \mathrm{E}+02$ & $1.12 \mathrm{E}+01$ & Category 2 \\
\hline Zr-95 & $2.22 E+06$ & $1.5 E+06$ & $7.0 \mathrm{E}+02$ & $1.48 \mathrm{E}+00$ & Category 2 \\
\hline $\mathrm{Nb}-95$ & $8.49 E+05$ & $4.3 E+05^{\beta}$ & $9.6 E+02^{C}$ & $1.97 \mathrm{E}+00$ & Category 2 \\
\hline $\mathrm{Nb}-95 \mathrm{~m}$ & $7.41 E+03$ & $4.3 E+05^{\beta}$ & $5.6 \mathrm{E}+03^{\mathrm{a}}$ & 1.72E-02 & Category 3 \\
\hline Tc-99 & $2.27 E+03$ & $3.8 E+06$ & $1.7 E+03$ & 5.96E-04 & Category 3 \\
\hline Ru-103 & $4.77 E+03$ & $4.3 E+05^{\beta}$ & $1.5 E+03^{b}$ & 1.19E-02 & Category 3 \\
\hline $\mathrm{Ru}-103 \mathrm{~m}$ & $4.31 E+03$ & $4.3 E+05^{\beta}$ & * & $1.00 \mathrm{E}-02$ & Category 3 \\
\hline Ru-106 & $4.64 \mathrm{E}+07$ & $6.5 E+03$ & $1.0 \mathrm{E}+02$ & $7.14 \mathrm{E}+03$ & Category 2 \\
\hline Rh-106 & $4.64 \mathrm{E}+07$ & $4.3 E+05^{\beta}$ & $1.96 \mathrm{E}+03^{\mathrm{C}}$ & $1.08 \mathrm{E}+02$ & Category 2 \\
\hline $\mathrm{Ag}-110$ & $5.10 \mathrm{E}+03$ & $4.3 E+05^{\beta}$ & * & 1.19E-02 & Category 3 \\
\hline $\mathrm{Ag}-110 \mathrm{~m}$ & $3.83 E+05$ & $5.3 E+05$ & $2.6 \mathrm{E}+02$ & $7.22 \mathrm{E}-01$ & Category 3 \\
\hline $\mathrm{Cd}-113 \mathrm{~m}$ & $1.53 E+04$ & $4.3 E+05^{\beta}$ & $1.1 E+01^{d}$ & $3.56 \mathrm{E}-02$ & Category 3 \\
\hline Sn-119m & $8.65 E+03$ & $4.3 E+05^{\beta}$ & $1.8 \mathrm{E}+03^{\mathrm{d}}$ & $2.01 \mathrm{E}-02$ & Category 3 \\
\hline Sn-123 & $3.19 E+04$ & $9.5 \mathrm{E}+05$ & $3.2 E+02$ & 3.36E-02 & Category 3 \\
\hline Sb-125 & $1.91 E+06$ & $4.3 E+05^{\beta}$ & $1.2 \mathrm{E}+03^{\mathrm{D}}$ & $4.44 \mathrm{E}+00$ & Category 2 \\
\hline Te-125m & $4.66 \mathrm{E}+05$ & $4.3 E+05^{\beta}$ & $7.2 \mathrm{E}+02^{\mathrm{a}}$ & $1.08 \mathrm{E}+00$ & Category 2 \\
\hline Te-127 & $1.79 \mathrm{E}+07$ & $4.3 E+05 \beta$ & $1.4 \mathrm{E}+05^{\mathrm{a}}$ & $4.16 \mathrm{E}+01$ & Category 2 \\
\hline Te-127m & $7.79 E+04$ & $1.5 E+05$ & $4.0 E+02$ & 5.19E-01 & Category 3 \\
\hline Te-129 & $3.52 E+00$ & $N / L$ & $2.2 \mathrm{E}+05^{\mathrm{e}}$ & $\mathrm{N} / \mathrm{A}$ & Radiological \\
\hline Te-129m & $5.41 E+00$ & $1.4 E+05$ & $4.0 E+02$ & 3.87E-05 & Radiological \\
\hline Cs-134 & $2.27 E+07$ & $6.0 E+04$ & $4.2 E+01$ & $3.78 \mathrm{E}+02$ & Category 2 \\
\hline Cs-137 & $2.04 E+07$ & $8.9 E+04$ & $6.0 E+01$ & $2.29 E+02$ & Category 2 \\
\hline $\mathrm{Ba}-137 \mathrm{~m}$ & $1.93 E+07$ & $N / L$ & $N / L$ & $\mathrm{~N} / \mathrm{A}$ & Category $2^{\star \star}$ \\
\hline Ce-141 & $1.89 \mathrm{E}+02$ & $3.3 E+06$ & $1.0 \mathrm{E}+03$ & 5.74E-05 & Radiological \\
\hline Ce-144 & $1.05 \mathrm{E}+08$ & $8.2 E+04$ & $1.0 \mathrm{E}+02$ & $1.28 \mathrm{E}+03$ & Category 2 \\
\hline Pr-144 & $1.05 E+08$ & $4.3 E+05^{\beta}$ & $1.04 \mathrm{E}+06^{\mathrm{C}}$ & $2.44 \mathrm{E}+02$ & Category 2 \\
\hline Pr-144m & $1.26 \mathrm{E}+06$ & $4.3 E+05^{\beta}$ & * & $2.94 \mathrm{E}+00$ & Category 2 \\
\hline
\end{tabular}




\begin{tabular}{|c|c|c|c|c|c|}
\hline $\mathrm{Pm}-147$ & $4.14 E+07$ & $8.4 E+05$ & $1.0 E+03$ & $4.92 E+01$ & Category 2 \\
\hline $\mathrm{Pm}-148 \mathrm{~m}$ & $2.62 E+01$ & $N / L$ & $3.6 \mathrm{E}+02^{\mathrm{a}}$ & N/A & Radiological \\
\hline $\mathrm{Sm}-151$ & $1.53 E+05$ & $9.9 E+05$ & $1.0 E+03$ & $1.54 \mathrm{E}-01$ & Category 3 \\
\hline Eu-154 & $1.60 E+05$ & $1.1 \mathrm{E}+05$ & $2.0 E+02$ & $1.45 \mathrm{E}+01$ & Category 2 \\
\hline Eu-155 & $8.38 E+05$ & $7.3 E+05$ & $9.4 E+02$ & $1.15 E+00$ & Category 2 \\
\hline T1-208 & $1.86 E+04$ & $4.3 E+05^{\beta}$ & * & $4.33 \mathrm{E}-02$ & Category 3 \\
\hline $\mathrm{Pb}-209$ & $1.92 E+01$ & $4.3 E+05^{\beta}$ & * & 4.47E-05 & Category 3 \\
\hline $\mathrm{Pb}-211$ & $3.65 E+01$ & $N / L$ & $6.2 \mathrm{E}+03^{\mathrm{d}}$ & N/A & Radiological \\
\hline $\mathrm{Pb}-212$ & $5.19 E+04$ & $4.3 E+05^{\beta}$ & $3.2 \mathrm{E}+02^{\mathrm{d}}$ & $1.21 \mathrm{E}-01$ & Category 3 \\
\hline $\mathrm{Bi}-211$ & $3.65 E+01$ & $5.5 E+01^{\alpha}$ & * & $6.64 \mathrm{E}-01$ & Category 3 \\
\hline $\mathrm{Bi}-212$ & $5.19 E+04$ & $4.3 E+05^{\beta}$ & $2.0 \mathrm{E}+03^{\mathrm{d}}$ & 1.21E-01 & Category 3 \\
\hline $\mathrm{Bi}-213$ & $1.92 E+01$ & $N / L$ & $3.2 \mathrm{E}+03^{\mathrm{d}}$ & N/A & Radiological \\
\hline Po-212 & $3.32 E+04$ & $5.5 E+01^{\alpha}$ & * & $6.04 E+02$ & Category 2 \\
\hline Po-213 & $1.88 E+01$ & $5.5 E+01 \alpha$ & * & $3.42 \mathrm{E}-01$ & Category 3 \\
\hline Po-215 & $3.65 E+01$ & $5.5 E+01^{\alpha}$ & $\star$ & $6.64 E-01$ & Category 3 \\
\hline Po-216 & $5.19 \mathrm{E}+04$ & $5.5 E+01^{\alpha}$ & * & $9.44 \mathrm{E}+02$ & Category 2 \\
\hline At-217 & $1.92 \mathrm{E}+01$ & $5.5 E+01^{\alpha}$ & * & $3.50 \mathrm{E}-01$ & Category 3 \\
\hline$R n-219$ & $3.65 E+01$ & $5.5 E+01^{\alpha}$ & * & $6.64 \mathrm{E}-01$ & Category 3 \\
\hline Rn-220 & $5.19 E+04$ & $5.5 \mathrm{E}+01^{\alpha}$ & $2.0 E+00^{d}$ & $9.44 E+02$ & Category 2 \\
\hline $\mathrm{Fr}-221$ & $1.92 \mathrm{E}+01$ & $5.5 \mathrm{E}+01^{\alpha}$ & * & $3.50 \mathrm{E}-01$ & Category 3 \\
\hline Ra-223 & $3.65 \mathrm{E}+01$ & $3.8 E+03$ & $6.2 E+01$ & $9.61 \mathrm{E}-03$ & Radiological \\
\hline Ra-224 & $5.19 E+04$ & $9.9 E+03$ & $2.0 E+02$ & $5.24 \mathrm{E}+00$ & Category 2 \\
\hline Ra-225 & $1.92 \mathrm{E}+01$ & $3.8 E+03$ & $7.2 \mathrm{E}+01$ & $5.06 \mathrm{E}-03$ & Radiological \\
\hline AC-225 & $1.92 E+01$ & $2.9 E+03$ & $3.2 E+01$ & $6.63 E-03$ & Radiological \\
\hline AC-227 & $3.76 \mathrm{E}+01$ & $4.3 E+00$ & $4.2 \mathrm{E}-02$ & $8.75 E+00$ & Category 2 \\
\hline Th-227 & $3.61 E+01$ & $5.5 E+01^{\alpha}$ & $3.2 E+01$ & $6.56 \mathrm{E}-01$ & Category 3 \\
\hline Th-228 & $5.17 \bar{E}+04$ & $9.2 \mathrm{E}+01$ & $1.0 E+00$ & $5.62 \mathrm{E}+02$ & Category 2 \\
\hline Th-229 & $1.92 \mathrm{E}+01$ & $5.5 E+01^{\alpha}$ & * & $13.50 \mathrm{E}-01$ & Category 3 \\
\hline Th-231 & $2.51 E+01$ & $5.5 \mathrm{E}+01^{\alpha}$ & $\star$ & $4.56 \mathrm{E}-01$ & Category 3 \\
\hline Th-232 & $3.78 \mathrm{E}+01$ & $1.8 \mathrm{E}+01$ & 1.0E-01 & $2.10 \mathrm{E}+00$ & Category 2 \\
\hline Th-234 & $4.75 E-01$ & $\mathrm{~N} / \mathrm{L}$ & $2.8 \mathrm{E}+03^{\mathrm{C}}$ & $\mathrm{N} / \mathrm{A}$ & Radiological \\
\hline $\mathrm{Pa}-231$ & $5.02 E+02$ & $5.5 E+01 \alpha$ & $2.0 \mathrm{E}-01^{\mathrm{d}}$ & $9.12 \mathrm{E}+00$ & Category 2 \\
\hline $\mathrm{Pa}-233$ & $1.89 \mathrm{E}+02$ & $N / L$ & $4.6 E+03^{d}$ & N/A & Radiological \\
\hline $\mathrm{Pa}-234 \mathrm{~m}$ & $4.75 \mathrm{E}-01$ & $4.3 E+05^{\beta}$ & $\mathrm{N} / \mathrm{L}$ & $1.11 \mathrm{E}-06$ & Category 3 \\
\hline U-232 & $9.00 \mathrm{E}+04$ & $5.5 E+01^{\alpha}$ & $8.2 \mathrm{E}-01^{\mathrm{a}}$ & $1.64 \mathrm{E}+03$ & Category 2 \\
\hline U-233 & $8.65 E+04$ & $2.2 E+02$ & $4.2 E+00$ & $3.93 E+02$ & Category 2 \\
\hline $\mathrm{U}-234$ & $4.22 E+03$ & $2.2 \mathrm{E}+02$ & $4.2 E+00$ & $1.92 \mathrm{E}+01$ & Category 2 \\
\hline $\mathrm{U}-235$ & $2.51 E+01$ & $2.4 E+02$ & $4.2 E+00$ & $1.05 \mathrm{E}-01$ & Category 3 \\
\hline U-236 & $7.24 \mathrm{E}+01$ & $5.5 E+01^{\alpha}$ & $4.2 \mathrm{E}+00^{6}$ & $1.32 E+00$ & Category 2 \\
\hline U-237 & $5.70 E+02$ & $\mathrm{~N} / \mathrm{L}$ & $1.4 \mathrm{E}+04^{\mathrm{d}}$ & N/A & Radiological \\
\hline U-238 & $1.85 \mathrm{E}+02$ & $2.4 E+02$ & $4.2 E+00$ & $7.72 \mathrm{E}-01$ & Category 3 \\
\hline
\end{tabular}




\begin{tabular}{|c|c|c|c|c|c|}
\hline $\mathrm{Np}-237$ & $1.94 E+01$ & $5.8 E+01$ & $4.2 \mathrm{E}-01$ & $3.34 \mathrm{E}-01$ & Category 3 \\
\hline Np-239 & $2.12 E+04$ & $4.3 E+05$ & $7.8 \mathrm{E}+03^{\mathrm{d}}$ & $4.93 E-02$ & Category 3 \\
\hline Pu-236 & $2.46 E+05$ & $5.5 \mathrm{E}+01^{\alpha}$ & $2.0 \mathrm{E}+00^{\mathrm{a}}$ & $4.48 E+03$ & Category 2 \\
\hline $\mathrm{Pu}-238$ & $1.14 \mathrm{E}+05$ & $6.2 \mathrm{E}+01$ & $6.2 \mathrm{E}-01$ & $1.84 E+03$ & Category 2 \\
\hline Pu-239 & $1.28 E+05$ & $5.6 \mathrm{E}+01$ & 5.2E-01 & $2.28 E+03$ & Category 2 \\
\hline Pu-240 & $2.15 E+07$ & $5.5 E+01^{\alpha} \alpha$ & $5.2 \mathrm{E}-01^{\mathrm{C}}$ & $3.91 E+05$ & Category 2 \\
\hline Pu-241 & $2.33 E+07$ & $2.9 E+03$ & $3.2 E+01$ & $8.04 E+03$ & Category 2 \\
\hline Am-241 & $1.14 E+05$ & $5.5 E+01$ & 5.2E-01 & $2.07 E+03$ & Category 2 \\
\hline$A m-242 m$ & $7.50 \mathrm{E}+02$ & $5.6 \mathrm{E}+01$ & $5.2 \mathrm{E}-01$ & $1.34 \mathrm{E}+01$ & Category 2 \\
\hline Am-242 & $7.48 E+02$ & $\mathrm{~N} / \mathrm{L}$ & $8.2 \mathrm{E}+03^{\mathrm{d}}$ & N/A & Radiological \\
\hline Am-243 & $2.12 E+04$ & $5.5 E+01$ & $5.2 E-01$ & $3.85 E+02$ & Category 2 \\
\hline $\mathrm{Cm}-242$ & $1.08 E+06$ & $1.7 E+03$ & $3.2 \mathrm{E}+01^{\mathrm{C}}$ & $6.34 E+02$ & Category 2 \\
\hline $\mathrm{Cm}-243$ & $1.08 \mathrm{E}+04$ & $5.5 E+01^{\alpha}$ & $8.2 E-01$ & $1.96 E+02$ & Category 2 \\
\hline $\mathrm{Cm}-244$ & $6.05 E+06$ & $5.5 E+01 \alpha$ & $1.04 E+00$ & $1.10 E+05$ & Category 2 \\
\hline $\mathrm{Cm}-246$ & $4.73 E+02$ & $5.5 E+01^{\alpha}$ & $5.2 \mathrm{E}-01^{\mathrm{C}}$ & $8.60 E+00$ & Category 2 \\
\hline Grand Total & $5.27 E+08$ & & Total ratio $=$ & $5.36 E+05$ & \\
\hline
\end{tabular}

\section{N/A Not Available}

N/L Not listed in DOE-STD-1027-92.

* These radioisotopes have extremely short half-lives $(<10 \mathrm{~min}$ ) and a Category 3 Threshold limit is difficult to determine for them. They are believed to be daughter isotopes. They are therfore compared to the Category 2 Threshold limits for alpha and beta-gamma emmiters per DOE-STD-1027-92, and categorized appropriately.

**Ba-137m is not listed as either an alpha or a beta-gamma emitter on the chart of nucleotides, so it is conservatively assumed to be a category 2 hazard, even though its half-life is 2.5 minutes.

a Category 3 Threshold limits obtained from SRT-SSA-930073 [13]

b Category 3 Threshold limits obtained from SRT-SSA-930011 [14]

c Category 3 Threshold limits obtained from SRT-LSA-93-0087 [15]

d Category 3 Threshold limits obtained from EPD-TAF-94-0008 [18]

e Category 3 Threshold limits obtained from SRT-SSA-940048 [19]

$\alpha$ Based on DOE-STD-1027-92 alpha emitter standard.

$\beta$ Based on DOE-STD-1027-92 beta-gamma emitter standard.

+ Reference 24 
Table 2. Chemical Inventory

\begin{tabular}{|l|c|c|c|c|c|}
\hline \multicolumn{1}{|c|}{ CHEMICAL } & CONCENTRATION+ & GAL.+ & $\begin{array}{c}\text { SPECIFIC } \\
\text { GRAVITY }\end{array}$ & LB/GAL & $\begin{array}{c}\text { INVENTORY, } \\
\text { LB }\end{array}$ \\
\hline \hline ALUMINUM NITRATE & $34.1 \%$ & 55 & 1.327 & 8.345 & 208 \\
\hline SULFURIC ACID/DW560 & $25.0 \%$ & 715 & 1.34 & 8.345 & 1999 \\
\hline NITRIC ACID/DW560 & $15.0 \%$ & 715 & 1.34 & 8.345 & 1199 \\
\hline ETHYLENE GLYCOL & $100.0 \%$ & 110 & 1.1 & 8.345 & 1010 \\
\hline ETHYLENE GLYCOL & $100.0 \%$ & 310 & 1.1 & 8.345 & 2846 \\
\hline NITRIC ACID & $50.0 \%$ & 2500 & 1.3043 & 8.345 & 13605 \\
\hline SODIUM HYDROXIDE & $50.0 \%$ & 2500 & 1.5074 & 8.345 & 15724 \\
\hline SODIUM NITRITE & $30.0 \%$ & 2500 & 1.3504 & 8.345 & 8452 \\
\hline PHOSPHORIC ACID & $75.0 \%$ & 585.5 & 1.576 & 8.345 & 5775 \\
\hline $\begin{array}{l}\text { ANHYYDROUS OXALIC } \\
\text { ACID }\end{array}$ & $100.0 \%$ & N/A & 1.653 & 8.345 & 525 \\
\hline
\end{tabular}

+ Reference 23

N/A Not Available (anhydrous oxalic acid is a solid) 
Table 3. Chemical Inventory and Comparison to Reportable Quantity Limits

\begin{tabular}{|c|c|c|c|c|}
\hline Chemical & $\begin{array}{c}\text { Inventory } \\
\text { (lb)+ }\end{array}$ & $\begin{array}{c}\text { Reportable } \\
\text { Quantitya } \\
\text { (Ib) }\end{array}$ & $\begin{array}{l}\text { Threshold } \\
\text { Planning } \\
\text { Quantityb } \\
\text { (lb) } \\
\end{array}$ & $\begin{array}{c}\text { Threshold } \\
\text { Quantityc } \\
\text { (lb) }\end{array}$ \\
\hline $34.1 \%$ Aluminum Nitrate & 208 & NL & $\mathrm{NL}$ & $\mathrm{NL}$ \\
\hline Azo Violet & 0.03 & $\mathrm{NL}$ & $\mathrm{NL}$ & $\mathrm{NL}$ \\
\hline \multicolumn{5}{|l|}{$\begin{array}{l}\text { 4-(p- } \\
\text { nitrophenyl)azolresorcinol }\end{array}$} \\
\hline \multicolumn{5}{|l|}{ magneson } \\
\hline Boric Acid & 100 & $\mathrm{NL}$ & $\mathrm{NL}$ & NL \\
\hline Celite 545 & 2700 & & & \\
\hline $\begin{array}{l}\text { flux calcined diatomaceous } \\
\text { earth }\end{array}$ & & $\mathrm{NL}$ & NL & NL \\
\hline crystalline silica & & $\mathrm{NL}$ & NL & $\mathrm{NL}$ \\
\hline cristobalite quartz & & $\mathrm{NL}$ & $\mathrm{NL}$ & NL \\
\hline \multicolumn{5}{|l|}{ DW-560 } \\
\hline $25 \%$ sulfuric acid & 1999 & 1000 & 1000 & $\mathrm{NL}$ \\
\hline $15 \%$ nitric acid & 1199 & 1000 & 1000 & 500 \\
\hline $2 \%$ hydrofluorisilic acid & & $\mathrm{NL}$ & $\mathrm{NL}$ & $\mathrm{NL}$ \\
\hline Ethylene Glycol & 1010 & $\mathrm{NL}$ & $\mathrm{NL}$ & $\mathrm{NL}$ \\
\hline Ethylene Glycol & 2846 & $\mathrm{NL}$ & $\mathrm{NL}$ & $\mathrm{NL}$ \\
\hline $\begin{array}{l}\text { Ion Exchange Resin (anion } \\
\text { form }\end{array}$ & $40 \mathrm{ft}^{3}$ & $\overline{N L}$ & NL & $\mathrm{NL}$ \\
\hline $\begin{array}{l}\text { Ion Exchange Resin (cation } \\
\text { form) }\end{array}$ & $30 \mathrm{ft}^{3}$ & $\mathrm{NL}$ & $\mathrm{NL}$ & $\mathrm{NL}$ \\
\hline $\begin{array}{l}\text { Kemp K-11 Vapoilsorb } \\
\text { activated bauxite }\end{array}$ & 250 & NL & NL & NL \\
\hline $\begin{array}{l}\text { Kemp K-25 Grade A Alumina } \\
\text { (alumina hydrate) }\end{array}$ & 250 & $\mathrm{NL}$ & $\mathrm{NL}$ & NL \\
\hline $50 \%$ Nitric Acid & 13605 & 1000 & 1000 & $\mathrm{NL}$ \\
\hline Oxalic Acid Anhydrous & 525 & $\mathrm{NL}$ & $\mathrm{NL}$ & $\mathrm{NL}$ \\
\hline $75 \%$ Phosphoric Acid & 5775 & 5000 & $\mathrm{NL}$ & $\mathrm{NL}$ \\
\hline Potassium Tetraborate & 100 & $\mathrm{NL}$ & $\mathrm{NL}$ & $\mathrm{NL}$ \\
\hline Soda Ash (sodium carbonate) & 100 & $\mathrm{NL}$ & $\mathrm{NL}$ & $\mathrm{NL}$ \\
\hline $\begin{array}{l}\text { Sodium Dichromate } \\
\text { Anhydrous }\end{array}$ & 1000 & $\mathrm{NL}$ & $\mathrm{NL}$ & $\mathrm{NL}$ \\
\hline $50 \%$ Sodium Hydroxide & 15724 & 1000 & NL & NL \\
\hline $30 \%$ Sodium Nitrite & 8452 & 100 & $\mathrm{NL}$ & $\mathrm{NL}$ \\
\hline \multicolumn{5}{|l|}{ Steam Cleaner $67-100$} \\
\hline $33 \%$ sodium metasilicate & 334 & $\mathrm{NL}$ & $\mathrm{NL}$ & $\mathrm{NL}$ \\
\hline $5 \%$ sodium hydroxide & 50 & 1000 & $\mathrm{NL}$ & $\mathrm{NL}$ \\
\hline
\end{tabular}

a Reportable Quantity as given in 40 CFR 302.4 [10]

b Threshold Planning Quantity as given in 40 CFR 355 [11]

C Threshold Quantity as given in 29 CFR 1910.119 [12]

NL - Not Listed in the associated CFR

+ Reference 23 
Table 4. Offsite Chemical Analysis Results and Equivalent ERPG Limits

\begin{tabular}{|c|c|c|c|c|}
\hline Chemical & $\begin{array}{c}\text { Inventory } \\
\text { lb* }^{*}\end{array}$ & $\begin{array}{c}\text { Release } \\
\text { Rate } \\
\text { mg/sec }\end{array}$ & $\begin{array}{c}\text { Offsite } \\
\text { Concentration } \\
\left(\chi / \mathrm{Q}=8.29 \mathrm{E}-06 \mathrm{sec} / \mathrm{m}^{3}\right) \\
\mathrm{mg} / \mathrm{m}^{3} \\
\end{array}$ & $\begin{array}{c}\text { ERPG-3 } \\
\text { Limit }^{+} \\
\mathrm{mg} / \mathrm{m}^{3} \\
\end{array}$ \\
\hline $25 \%$ SULFURIC ACID & $2.00 E+03$ & $1.01 E+04$ & 8.36E-02 & $3.00 E+01$ \\
\hline 15\% NITRIC ACID & $1.20 \mathrm{E}+03$ & $6.05 E+03$ & 5.01E-02 & $7.86 E+01$ \\
\hline $50 \%$ NITRIC ACID & $1.36 E+04$ & $6.86 E+04$ & 5.69E-01 & $7.86 \mathrm{E}+01$ \\
\hline ETHYLENE GLYCOL & $1.01 E+03$ & $5.09 E+03$ & 4.22E-02 & $1.29 E+02$ \\
\hline ETHYLENE GLYCOL & $2.85 E+03$ & $1.44 E+04$ & 1.19E-01 & $1.29 E+02$ \\
\hline 75\% PHOSPHORIC ACID & $5.78 E+03$ & $2.91 E+04$ & $2.42 E-01$ & $1.00 \mathrm{E}+04$ \\
\hline 50\% SODIUM HYDROXIDE & $1.57 E+04$ & $7.93 E+04$ & $6.58 \mathrm{E}-01$ & $1.00 \mathrm{E}+02$ \\
\hline ANHYDROUS OXALIC ACID & $5.25 E+02$ & $2.65 E+03$ & 2.20E-02 & $5.00 E+02$ \\
\hline
\end{tabular}

* Reference 23

+IDLH Limit for Phosphoric Acid; TLV Limit for Ethylene Glycol

Table 5. Onsite Chemical Analysis Results and Equivalent ERPG Limits

\begin{tabular}{|c|c|c|c|c|}
\hline Chemical & $\begin{array}{c}\text { Inventory } \\
\mathbf{I b}^{\mathrm{a}}\end{array}$ & $\begin{array}{c}\text { Release } \\
\text { Rate } \\
\text { mg/sec } \\
\end{array}$ & $\begin{array}{c}\text { Onsite } \\
\text { Concentration } \\
\left(\chi / \mathrm{Q}=5.55 \mathrm{E}-03 \mathrm{sec} / \mathrm{m}^{3}\right) \\
\mathrm{mg} / \mathrm{m}^{3} \\
\end{array}$ & $\begin{array}{c}\text { ERPG-3 } \\
\text { Limit }^{+} \\
\mathrm{mg} / \mathrm{m}^{3} \\
\end{array}$ \\
\hline $25 \%$ SULFURIC ACID & $2.00 E+03$ & $1.01 E+04$ & $5.60 \mathrm{E}+01$ & $3.00 E+01$ \\
\hline $15 \%$ NITRIC ACID & $1.20 \mathrm{E}+03$ & $6.05 E+03$ & $3.36 \mathrm{E}+01$ & $7.86 \mathrm{E}+01$ \\
\hline $50 \%$ NITRIC ACID & $1.36 \mathrm{E}+04$ & $6.86 \mathrm{E}+04$ & $3.81 E+02$ & $7.86 \mathrm{E}+01$ \\
\hline ETHYLENE GLYCOL & $1.01 E+03$ & $5.09 E+03$ & $2.83 E+01$ & $1.29 E+02$ \\
\hline ETHYLENE GLYCOL & $2.85 E+03$ & $1.44 E+04$ & $7.97 E+01$ & $1.29 E+02$ \\
\hline 75\% PHOSPHORIC ACID & $5.78 E+03$ & $2.91 E+04$ & $1.62 \mathrm{E}+02$ & $1.00 \mathrm{E}+04$ \\
\hline $50 \%$ SODIUM HYDROXIDE & $1.57 E+04$ & $7.93 E+04$ & $4.40 \mathrm{E}+02$ & $1.00 E+02$ \\
\hline ANYDROUS OXALIC ACID & $5.25 E+02$ & $2.65 E+03$ & $1.47 E+01$ & $5.00 \mathrm{E}+02$ \\
\hline
\end{tabular}

+IDLH Limit for Phosphoric Acid; TLV Limit for Ethylene Glycol

*Onsite concentration exceeds the ERPG Limit

${ }^{a}$ Reference 23 
Table 6. Local Chemical Analysis Results and Equivalent ERPG Limits

\begin{tabular}{|c|c|c|c|c|}
\hline Chemical & $\begin{array}{c}\text { Inventory } \\
\text { lb }^{\mathrm{a}}\end{array}$ & $\begin{array}{c}\text { Release } \\
\text { Rate } \\
\mathrm{mg} / \mathrm{sec}\end{array}$ & $\begin{array}{c}\text { Local } \\
\text { Concentration } \\
\left(\chi / \mathrm{Q}=1.75 \mathrm{E}-02 \mathrm{sec} / \mathrm{m}^{3}\right) \\
\mathrm{mg} / \mathrm{m}^{3} \\
\end{array}$ & $\begin{array}{c}\text { ERPG-3 } \\
\text { Limit }^{+} \\
\mathrm{mg}^{3} \mathrm{~m}^{3} \\
\end{array}$ \\
\hline $25 \%$ SULFURIC ACID & $2.00 E+03$ & $1.01 \mathrm{E}+04$ & $1.76 E+02$ & $3.00 \mathrm{E}+01$ \\
\hline $15 \%$ NITRIC ACID & $1.20 E+03$ & $6.05 E+03$ & $1.06 E+02$ & $7.86 \mathrm{E}+01$ \\
\hline $50 \%$ NITRIC ACID & $1.36 \mathrm{E}+04$ & $6.86 \mathrm{E}+04$ & $1.20 E+03$ & $7.86 \mathrm{E}+01$ \\
\hline ETHYLENE GLYCOL & $1.01 \mathrm{E}+03$ & $5.09 \mathrm{E}+03$ & $8.92 \mathrm{E}+01$ & $1.29 E+02$ \\
\hline ETHYLENE GLYCOL & $2.85 E+03$ & $1.44 E+04$ & $2.51 E+02$ & 1.29E+02 \\
\hline $75 \%$ PHOSPHORIC ACID & $5.78 E+03$ & $2.91 \mathrm{E}+04$ & $5.10 E+02$ & $1.00 \mathrm{E}+04$ \\
\hline $50 \%$ SODIUM HYDROXIDE & 1.57E+04 & $7.93 E+04$ & $1.39 \mathrm{E}+03$ & $1.00 \mathrm{E}+02$ \\
\hline ANYDROUS OXALIC ACID & $5.25 E+02$ & $2.65 E+03$ & $4.63 E+01$ & $5.00 \mathrm{E}+02$ \\
\hline
\end{tabular}

${ }^{+}$IDLH Limit for Phosphoric Acid; TLV Limit for Ethylene Glycol

* Local concentration exceeds the ERPG Limit

${ }^{a}$ Reference 23

Table 7. Recommended Nonradiological Hazard Categorization Guidelines For Use With DOE Order 5480.23

\begin{tabular}{|c|c|c|}
\hline $\begin{array}{c}\text { Hazard } \\
\text { Category }\end{array}$ & $\begin{array}{c}\text { Receptor } \\
\text { Location }\end{array}$ & $\begin{array}{c}\text { Recommended } \\
\text { Guidelines }\end{array}$ \\
\hline \hline 1 & Offsite & $\begin{array}{c}\geq \text { ERPG-3 } \\
2.00 \mathrm{E}+00 \mathrm{ICR}\end{array}$ \\
\hline 2 & Onsite & $\begin{array}{c}\geq \text { ERPG-3 } \\
2.00 \mathrm{E}+00 \mathrm{ICR}\end{array}$ \\
\hline 3 & Local & $\geq$ ERPG-3 \\
& & $2.00 \mathrm{E}+00 \mathrm{ICR}$ \\
\hline
\end{tabular}


Table 8. Fissile Materials Inventory and Criticality Limits

\begin{tabular}{|c|c|c|c|c|}
\hline Radionuclide & $\begin{array}{c}\text { Activity } \\
(\mathbf{C i})^{\mathrm{a}}\end{array}$ & $\begin{array}{c}\text { Specific } \\
\text { Activity } \\
(\mathrm{Ci} / \mathbf{g})+\end{array}$ & $\begin{array}{c}\text { Mass of } \\
\text { Radionuclide } \\
(\mathbf{g})\end{array}$ & $\begin{array}{c}\text { Minimum } \\
\text { Critical Mass } \\
(\mathbf{g})^{*}\end{array}$ \\
\hline & & & & \\
\hline $\mathrm{U}-233$ & $8.65 \mathrm{E}+04$ & $9.5 \mathrm{E}-03$ & $9.10 \mathrm{E}+06$ & 500 \\
\hline $\mathrm{U}-235$ & $2.51 \mathrm{E}+01$ & $2.1 \mathrm{E}-06$ & $1.19 \mathrm{E}+07$ & 700 \\
\hline $\mathrm{Pu}-239$ & $1.28 \mathrm{E}+05$ & $6.2 \mathrm{E}-02$ & $2.06 \mathrm{E}+06$ & 450 \\
\hline
\end{tabular}

* as stated in DOE-STD-1027-92

+ as stated in CFR 10, Part 71, Appendix A [25]

${ }^{a}$ Reference 24 


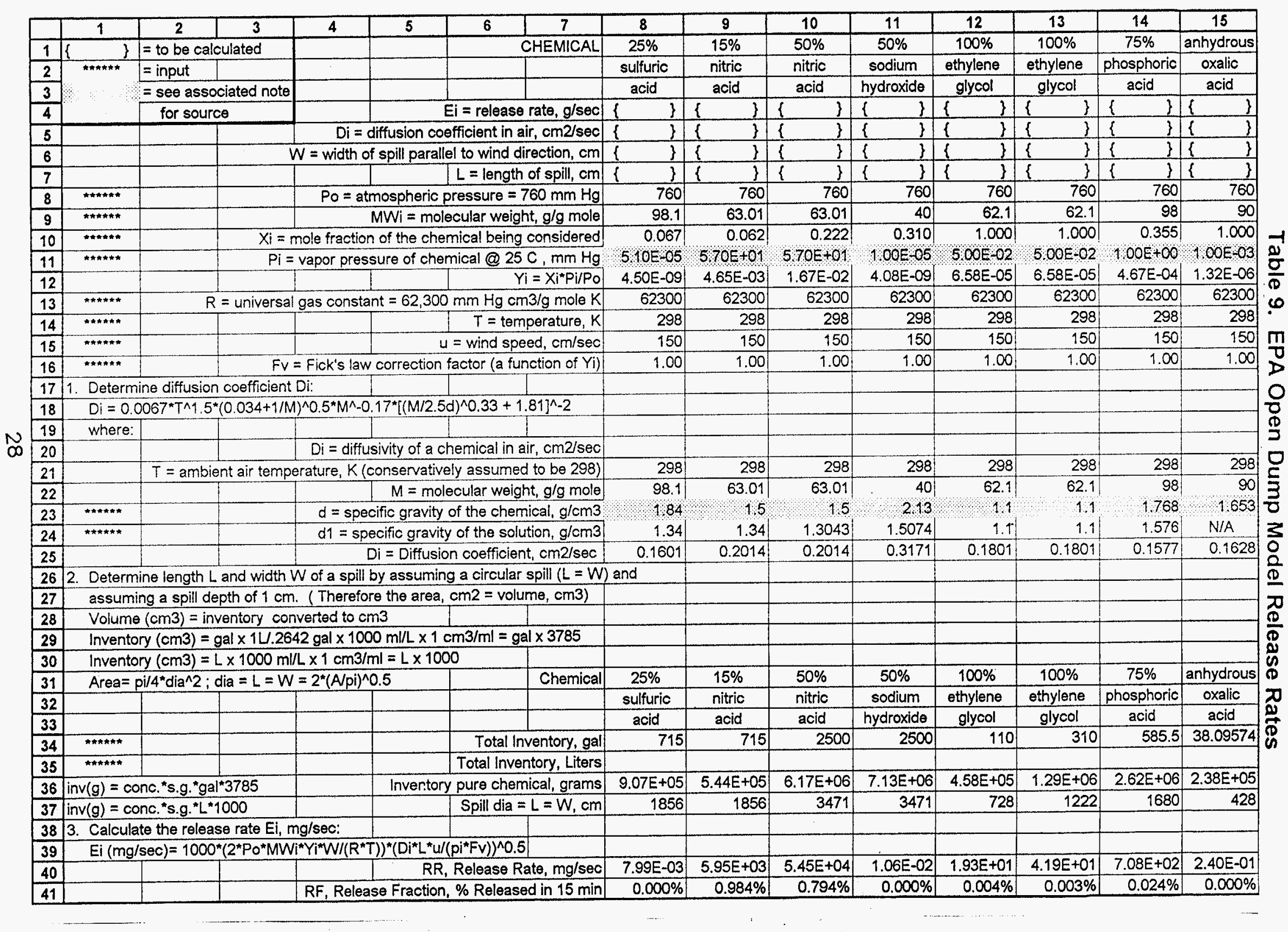

